\title{
Inquiry-Based Science Learning Through School Gardening Activities: Wonderful Experience Through Participatory Action Research
}

\author{
Kamal Prasad Acharya \\ Department of Science and Environment Education, Central Department of Education, Tribhuvan University, Kathmandu, Nepal \\ Email address: \\ kamalacharya@tucded.edu.np \\ To cite this article: \\ Kamal Prasad Acharya. Inquiry-Based Science Learning Through School Gardening Activities: Wonderful Experience Through Participatory \\ Action Research. International Journal of Elementary Education. Vol. 7, No. 3, 2018, pp. 40-45. doi: 10.11648/j.ijeedu.20180703.11
}

Received: October 18, 2018; Accepted: November 21, 2018; Published: December 20, 2018

\begin{abstract}
The present paper is an attempt to assess the skills for school gardening for inquiry-based science learning of fourth, fifth, sixth, seventh and eighth grade basic level students of public schools. To achieve this aim, a set of questionnaires was developed to be administered to basic level students. A sample of $404(\mathrm{~N}=388)$ were selected from one action and four reference schools to take part in the present study located in Chitwan and Nawalparasi districts of the Terai region of Nepal. Students from all the selected schools participated in school gardening activities as part of their science curriculum aiming at motivating inquiry-based science teaching and learning. A quantitative analysis involving the use of frequency, Chi-square test at 0.05 level of significance and phi was conducted to see the association between the variables: religion, caste, and language and gardening skills. Weighted percentages were calculated to examine the gardening skills for experiencing inquiry-based science learning. The results showed that school gardening skills were performed better (94.4\%) by students belonging to Brahmin/Chhetri Hindu background than the others. The findings also showed a weak association between religious and caste/ethnicity backgrounds of the students and gardening skills. There was no statistically significant difference $(\alpha=0.05)$ between gardening skills of students and the religion they follow, either. Gardening enthusiasm with basic skills varies among students with different basic demographic background of students.
\end{abstract}

Keywords: Gardening Skills, Inquiry-Based Science Learning, Engagement

\section{Introduction}

Education in Nepal was long based on home schooling and Gurukul Education from the primary schools to the university level has been modeled from the very inception on the Indian system. In Nepal, an understanding of basic science is critical in today's society which is increasingly technology driven. Nepalese people use the knowledge of science on a daily basis to make decisions on evolving issues and technologies. It is becoming apparent that public schools in Nepal need to educate students on basic science literacy issues since they will be the ones making future decisions. In order to understand these issues and develop informed opinions, a society needs to have the basic understanding of the principles of science education [1]. Basic science skills are often referred to as science literacy [2], which can be defined as the knowledge and understanding of scientific concepts and processes required for personal decisions making participation in civic and cultural affairs [3].

In line with the recently adopted Global Goals for Sustainable Development, this study aims to catalyze improvements in the quality of teaching and learning science at the basic education level in Nepal through innovative, transformative and contextualized pedagogical approaches. The uniform nature of the national science curriculum at the schools has faced criticisms for not being sufficiently contextual and practical to capture all aspirations and topographies in Nepal. The vast majority of classroom teaching includes didactic teacher-centered lectures [4]. The novice and some professionally motivated science teachers are more likely to use child-centered methods and strategies inside classroom. As far as assessment is concerned, standardized testing has encouraged rote learning and reproduction on the part of students rather than creating their 
own knowledge.

Science education is the field concerned with sharing science content and process to the pupil and from pupil to the people to increase scientific literacy $[5,7,8]$. We've known for years that there are better and more effective ways to educate our students than the current school system. It takes a long time for institutions such as schools to change from the status quo, even when everyone can see that there is a desperate need to do so. Perhaps one of the greatest difficulties in the schools face today in Nepal is the challenge of engaging students and creating excitement about science learning. Engagement is possible by adopting garden pedagogy [3]. Traditionally, our educational endeavor has been pre-occupied with filling buckets or teaching students to recall specific content given to them through lecture [2]. In order to engage students, attention must be paid by educators to the capacities, interests and habits of students [9-11]. In essence, effective engagement of students requires engaging the imagination and lighting the fire of creativity [12]. Integrating science teaching and learning with the research through school garden, a higher order thinking can be developed among our students [14]. It is with this paradox in mind that we turn our attention to the future of science education research and the changing paradigms through school gardening that will shape the society as a whole.

\subsection{Context}

Science learning beyond the classrooms is a recent trend to learn science in the context of Nepal. Outdoor classroom science activities provides a meaningful way to engage students in practical activities, giving them real experience of collecting and analysing data, and making predictions in the real world, beyond the limitations of the science classroom or laboratory [15]. Providing students with real quality learning activities in relevant situations beyond the walls of the classroom is vital for helping them appreciate their first hand experiences in the school garden forms a variety perspectives [16]. Experiences outside the classroom also enhances learning by providing students with opportunities to practice skills of inquiry, and problem solving in everyday situations.

This study explored the relationship between the language, ethnicity and religious beliefs with basic gardening skills for inquiry-based science learning integrated with garden pedagogy. It explores the knowledge regarding selective gardening skills such as plough the land, soil preparation, sow seeds, care for the saplings, watering plants and the use of tools among 388 students of 4 to 8 grades before starting gardening intervention packages.

The respects and acknowledges the rights of all citizens including students of all ethnic groups, cultures and religions [17]. There is a provision of the right to childfriendly justice. Basic Education Curriculum Framework has highlighted national educational objectives not only to respect, acknowledge and protect all the cultures, social values, and social collaboration but also to create social equality and inclusive society regardless difference in different genders, cultures and religions.

Policy reform documents value inquiry-based learning in Nepal [18]. Science learning primarily based on learning experiences. It is based on the theory of constructivism which is the main part of observation and scientific study about how people learn. Comprehensive understanding of inquiry-based learning supported by the participatory action research (PAR) approach through the development of higher-level sequential thinking involved in the co-creation of knowledge in science among the students.

\subsection{Purpose of the Study}

The study examined how the school garden develops an inquiry among the basic school students' attitudes about science learning among the different demographic characteristics. To improve the quality of teaching and learning science at the basic education level (grades 4-8) in Nepal through garden pedagogy, an assessment is required before intervention. It will ultimately help in the transformation classroom pedagogy from chalk and talk method of inquiry-based science learning.

\section{Methodology: Method and Materials}

Quantitative aspect of the research applied Participatory Action Research (PAR) approach in which the basic level school students (co-researchers) help for the intervention activities in the school gardening activities along with the science teachers and me as a co-researcher.

\subsection{Population and Sample of the Study}

Table 1. Sample schools and the total number of students.

\begin{tabular}{lll}
\hline Name of the Schools & Number & \% \\
\hline Bag Devi Basic School (feeder) & 38 & 9.4 \\
Jana Ekata Basic School (feeder) & 77 & 19.1 \\
Jan Jiwan High School (leader) & 209 & 51.7 \\
National Basic School (feeder) & 50 & 12.4 \\
Nawa Durga Basic School (feeder) & 30 & 7.4 \\
Total & 404 & 100.0 \\
\hline
\end{tabular}

A total of $404(\mathrm{~N}=388)$ students (Table 2) from five public schools (Table 1) who were in the four to eighth graders were recruited for this study because they were at the critical age when students tend to increase interest in doing practical activities in science (Dobbs, Relf \& McDaniel, 1999). Number of the participants were 388 that help to ensure quality inquiry-based learning using school gardening activities. Information of students as per the religion indicated that $73.5 \%$ were Hindus, $17.8 \%$ were Buddhists and $8.7 \%$ were Muslim. In addition, $40.8 \%$ were Chhetris, $25.7 \%$ were Brahmin, $14.2 \%$ were Magar, $9.5 \%$ were Newar, $7 \%$ were Tharus, and $2.8 \%$ were highly marginalized ethnic group. In the same way, $73.5 \%$ of the students spoke Nepali language as the mother tongue; $1.2 \%$ was Newari, Tamang $7.6 \%$, Tharu $10.4 \%$, Magar $1.4 \%$, Darai $2.8 \%$ and $3.1 \%$ (highly marginalized Chepang). The age of the students 
ranged from 8 to 10 years old (18\% of participants), from 11 to 13 years old $(62.5 \%$ of the participants), from 14 to 16 years old $(19.5 \%$ of the participants) and only $0.2 \%$ participants were at the age of 17 years at the time of the study.

Total number of students participated in the study is on Table 2.

Table 2. Number of students in each class.

\begin{tabular}{lll}
\hline Class & Number & \% \\
\hline 4 & 45 & 11.1 \\
5 & 57 & 14.1 \\
6 & 96 & 23.8 \\
7 & 105 & 26.0 \\
8 & 101 & 25.0 \\
Total & 404 & 100.0 \\
\hline
\end{tabular}

\subsection{Instruments}

Science survey test instrument was developed by the coresearchers (myself) and the science teachers of the action and the reference schools. Participating teachers were familiar to participatory action research approach by our prolonged engagement in the field and the inquiry-based science learning. The survey questions were related with the basic gardening skills such as the knowledge of plough the land, soil preparation, mixing compost manure and urine, care of plants and the use of tools in the school garden and how it can be linked in the science curriculum. The goal is to develop instruments that were gradeappropriate to assess the knowledge of skills as per their language, religion and ethnicity and how these factors affect inquiry-based science learning.

\section{Data Analysis}

Simple frequency, chi-square test at 0.05 level of significance and phi were performed in order to understand whether there is an association between the basic public school students with the school gardening skills in terms of language, ethnicity and religion variables. Before conducting Chi-square test analysis, the assumptions of the analysis were checked. The followings were tested, respectively (a) independence of observations (b) homogeneity of variable (c) two variables should be measured at an ordinal or nominal level (d) two variables should consist of two or more categorical, independent groups (e) the levels (or categories) of the variables should be mutually exclusive. In all statistical tests, $\alpha=0.05$ significance level was used in order to see the association and phi was calculated by using SPSS programme of data analysis.

\section{Result and Discussion}

Demographic characteristics of the sampled students is given in Table 3. About one third (29.2\%) population of the sampled students are from the highly marginalized population. Diverse group of students in-terms of ethnicity, religion and language are studying the sampled school.

Table 3. Background characteristics of households/respondents.

\begin{tabular}{llll}
\hline & $\begin{array}{l}\text { Background } \\
\text { characteristics }\end{array}$ & Total & \\
\cline { 2 - 4 } & & N & \% \\
\hline & Dalit & 118 & 29.2 \\
& Janajati & 200 & 49.5 \\
Caste/Ethnicity & Madhesi & 7 & 1.7 \\
& Brahman/Chhetri & 79 & 19.6 \\
& Buddhist & 72 & 17.8 \\
Religion & Hindu & 297 & 73.5 \\
& Christian & 35 & 8.7 \\
Language Spoken: Tamang & Yes & 5 & 1.2 \\
& No & 372 & 92.1 \\
Language Spoken: Tharu & Yes & 32 & 7.9 \\
& No & 359 & 89.1 \\
Language Spoken: Magar & Yes & 44 & 10.9 \\
& No & 398 & 98.5 \\
Language Spoken: Darai & Yes & 6 & 1.5 \\
& No & 391 & 97.0 \\
Language Spoken: Chepang & Yes & 12 & 3.0 \\
Total & No & 390 & 96.8 \\
\hline
\end{tabular}

Inferential statistics of the association between the basic school gardening skills (plough the land and soil preparation) with the religion of the students in Table 4 . It shows the knowledge of gardening skill related to ploughing the land in the school garden to prepare soil for planting vegetables and flowers. This skill seems better among Brahmin students who follow Hinduism (94.4\%) and Dalit Hindus (80.5\%). It shows that Brahmin parents engage agriculture for livelihood what was shown by the students' interview and focus group discussion (FGD, students). The skills of gardening transformed from the parents to the children. This knowledge ultimately help students to understand the concepts of science which makes science performance better. However, there is no significance difference between the ploughing gardening skills and ethnicity and religion of students.

Table 4. Gardening skills: Ploughing land in school garden.

\begin{tabular}{|c|c|c|c|c|c|}
\hline \multirow{2}{*}{ Caste/Ethnicity } & & \multicolumn{3}{|l|}{ Religion } & \multirow{2}{*}{ Total } \\
\hline & & Buddhist & Hindu & Christian & \\
\hline \multirow{4}{*}{ Dalit } & \multirow{4}{*}{ Skills of pupils for school gardening: Ploughing land } & $\mathrm{n}<5$ & $80.5 \%$ & $18.2 \%$ & $100.0 \%$ \\
\hline & & $\mathrm{n}<5$ & $38.3 \%$ & $63.6 \%$ & $32.8 \%$ \\
\hline & & $\mathrm{n}<5$ & $26.4 \%$ & $6.0 \%$ & $32.8 \%$ \\
\hline & & $49 \mathrm{a}$ & $57_{\mathrm{b}}$ & $7 \mathrm{~b}$ & 113 \\
\hline \multirow{4}{*}{ Janajati } & \multirow{4}{*}{ Skills of pupils for school gardening: Ploughing land } & $43.4 \%$ & $50.4 \%$ & $6.2 \%$ & $100.0 \%$ \\
\hline & & $96.1 \%$ & $35.2 \%$ & $31.8 \%$ & $48.1 \%$ \\
\hline & & $20.9 \%$ & $24.3 \%$ & $3.0 \%$ & $48.1 \%$ \\
\hline & & $<5_{\mathrm{a}}$ & $<5_{\mathrm{a}}$ & $<5_{\mathrm{a}}$ & $<5$ \\
\hline
\end{tabular}




\begin{tabular}{|c|c|c|c|c|c|}
\hline \multirow{2}{*}{ Caste/Ethnicity } & & \multicolumn{3}{|l|}{ Religion } & \multirow{2}{*}{ Total } \\
\hline & & Buddhist & Hindu & Christian & \\
\hline \multirow{4}{*}{ Dalit } & \multirow{4}{*}{ Skills of pupils for school gardening: Ploughing land } & $\mathrm{n}<5$ & $80.5 \%$ & $18.2 \%$ & $100.0 \%$ \\
\hline & & $\mathrm{n}<5$ & $38.3 \%$ & $63.6 \%$ & $32.8 \%$ \\
\hline & & $\mathrm{n}<5$ & $26.4 \%$ & $6.0 \%$ & $32.8 \%$ \\
\hline & & $49 \mathrm{a}$ & $57 \mathrm{~b}$ & $7 \mathrm{~b}$ & 113 \\
\hline \multirow{3}{*}{ Madhesi } & \multirow{3}{*}{ Skills of pupils for school gardening: Ploughing land } & $\mathrm{n}<5$ & $\mathrm{n}<5$ & $\mathrm{n}<5$ & $100.0 \%$ \\
\hline & & $\mathrm{n}<5$ & $\mathrm{n}<5$ & $\mathrm{n}<5$ & $\mathrm{n}<5$ \\
\hline & & $<5_{\mathrm{a}}$ & $41_{\mathrm{b}}$ & $<5_{\mathrm{a}}$ & 42 \\
\hline \multirow{4}{*}{ Brahnin/Chhetri } & \multirow{4}{*}{ Skills of pupils for school gardening: Ploughing land } & $\mathrm{n}<5$ & $94.4 \%$ & $\mathrm{n}<5$ & $100.0 \%$ \\
\hline & & $\mathrm{n}<5$ & $23.6 \%$ & $\mathrm{n}<5$ & $18.6 \%$ \\
\hline & & $\mathrm{n}<5$ & $17.5 \%$ & $\mathrm{n}<5$ & $18.6 \%$ \\
\hline & & 68 & 288 & 32 & 388 \\
\hline
\end{tabular}

Another gardening skill among the students was sowing the seeds to grow flowers and vegetables in the school garden. It shows that Dalit (marginalized group) students have better gardening skills i.e., sowing seeds $(70.7 \%)$ than that of Janajati students. Again, Brahmin/Chhetri students who follow Hinduism have good skills of sowing seeds $(60.3 \%)$ and least among the Janajati Christian students (46.3\%). Result showed that there is no significance difference between the sowing seeds skills among public school students in relation with caste and religion (Table 5).

Table 5. Gardening skills: Sowing seeds in the school garden.

\begin{tabular}{|c|c|c|c|c|c|}
\hline \multirow{2}{*}{ Caste/Ethnicity } & & \multicolumn{3}{|l|}{ Religion } & \multirow{2}{*}{ Total } \\
\hline & & Buddhist & Hindu & Christian & \\
\hline \multirow{4}{*}{ Dalit } & \multirow{4}{*}{ Skills of pupils for school gardening: Sow the seeds } & $\mathrm{n}<5$ & $70.7 \%$ & $75.0 \%$ & $71.6 \%$ \\
\hline & & $\mathrm{n}<5$ & $60.3 \%$ & $10.3 \%$ & $71.6 \%$ \\
\hline & & $<5$ & 99 & 16 & 116 \\
\hline & & $100.0 \%$ & $100.0 \%$ & $100.0 \%$ & $100.0 \%$ \\
\hline \multirow{4}{*}{ Janajati } & \multirow{4}{*}{ Skills of pupils for school gardening: Sow the seeds } & $77.8 \%$ & $59.8 \%$ & $46.2 \%$ & $64.8 \%$ \\
\hline & & $25.4 \%$ & $36.3 \%$ & $3.1 \%$ & $64.8 \%$ \\
\hline & & 63 & 117 & 13 & 193 \\
\hline & & $100.0 \%$ & $100.0 \%$ & $100.0 \%$ & $100.0 \%$ \\
\hline \multirow{4}{*}{ Madhesi } & \multirow{4}{*}{ Skills of pupils for school gardening: Sow the seeds } & $\mathrm{n}<5$ & $\mathrm{n}<5$ & $\mathrm{n}<5$ & $\mathrm{n}<5$ \\
\hline & & $\mathrm{n}<5$ & $\mathrm{n}<5$ & $\mathrm{n}<5$ & $\mathrm{n}<5$ \\
\hline & & $<5$ & $<5$ & $<5$ & 7 \\
\hline & & $100.0 \%$ & $100.0 \%$ & $100.0 \%$ & $100.0 \%$ \\
\hline \multirow{4}{*}{ Brahmin/Chhetri } & \multirow{4}{*}{ Skills of pupils for school gardening: Sow the seeds } & $<5_{a}$ & $41_{\mathrm{a}}$ & $<5 \mathrm{a}$ & 42 \\
\hline & & $\begin{array}{l}\mathrm{n}<5 \\
\mathrm{n}<5\end{array}$ & $\begin{array}{l}60.3 \% \\
56.9 \%\end{array}$ & $n<5$ & $\begin{array}{l}58.3 \% \\
58.3 \%\end{array}$ \\
\hline & & $<5$ & 68 & $<5$ & 72 \\
\hline & & $100.0 \%$ & $100.0 \%$ & $100.0 \%$ & $100.0 \%$ \\
\hline
\end{tabular}

The association $(\mathrm{Phi}=0.461)$ between the gardening skills and the religion and the caste of the students is weak but there is no significant difference $(\alpha=0.05)$.

Table 6. Gardening skills: Taking out weeds in the school garden.

\begin{tabular}{|c|c|c|c|c|c|}
\hline \multirow{2}{*}{ Caste/Ethnicity } & & \multicolumn{3}{|l|}{ Religion } & \multirow{2}{*}{ Total } \\
\hline & & Buddhist & Hindu & Christian & \\
\hline \multirow{4}{*}{ Dalit } & \multirow{4}{*}{ Skills of pupils for school gardening: Takeout weeds } & $\mathrm{n}<5$ & $85.3 \%$ & $13.8 \%$ & $100.0 \%$ \\
\hline & & $\mathrm{n}<5$ & $34.4 \%$ & $50.0 \%$ & $29.9 \%$ \\
\hline & & $\mathrm{n}<5$ & $25.5 \%$ & $4.1 \%$ & $29.9 \%$ \\
\hline & & $63_{\mathrm{a}}$ & $117_{\mathrm{b}}$ & $13_{\mathrm{b}}$ & 193 \\
\hline \multirow{4}{*}{ Janajati } & \multirow{4}{*}{ Skills of pupils for school gardening: Takeout weeds } & $32.6 \%$ & $60.6 \%$ & $6.7 \%$ & $100.0 \%$ \\
\hline & & $92.6 \%$ & $40.6 \%$ & $40.6 \%$ & $49.7 \%$ \\
\hline & & $16.2 \%$ & $30.2 \%$ & $3.4 \%$ & $49.7 \%$ \\
\hline & & $<5_{a}$ & $<5_{\mathrm{a}}$ & $<5_{\mathrm{a}}$ & 7 \\
\hline \multirow{4}{*}{ Madhesi } & \multirow{4}{*}{ Skills of pupils for school gardening: Takeout weeds } & $\mathrm{n}<5$ & $\mathrm{n}<5$ & $\mathrm{n}<5$ & $100.0 \%$ \\
\hline & & $\mathrm{n}<5$ & $\mathrm{n}<5$ & $\mathrm{n}<5$ & $1.8 \%$ \\
\hline & & $\mathrm{n}<5$ & $\mathrm{n}<5$ & $\mathrm{n}<5$ & $1.8 \%$ \\
\hline & & $<5_{\mathrm{a}}$ & $68_{\mathrm{b}}$ & $<5_{\mathrm{a}}$ & 72 \\
\hline \multirow{4}{*}{ Brahmin/Chhetri } & \multirow{4}{*}{ Skills of pupils for school gardening: Takeout weeds } & $\mathrm{n}<5$ & $94.4 \%$ & $\mathrm{n}<5$ & $100.0 \%$ \\
\hline & & $\mathrm{n}<5$ & $23.6 \%$ & $\mathrm{n}<5$ & $18.6 \%$ \\
\hline & & $\mathrm{n}<5$ & $17.5 \%$ & $\mathrm{n}<5$ & $18.6 \%$ \\
\hline & & 68 & 288 & 32 & 388 \\
\hline Total & & $17.5 \%$ & $74.2 \%$ & $8.2 \%$ & $100.0 \%$ \\
\hline
\end{tabular}


Skills of students for school gardening in terms of watering and caring plants is seems good among the Dalit students who follow Buddhism (85.5\%) and Janajati Hindus (60.6\%) and least (13.8\%) among Dalit Christian students. The association between watering plants in the school garden and religion as well as caste shown by chi-square value $(0.796$ at $\alpha=0.05)$ shows no significance. Weak association between these two variables seems weak by Phi (0.066).

Table 7. Gardening skills: Taking out weeds in the school garden.

\begin{tabular}{|c|c|c|c|c|c|}
\hline \multirow{2}{*}{ Caste/Ethnicity } & & \multicolumn{3}{|l|}{ Religion } & \multirow{2}{*}{ Total } \\
\hline & & Buddhist & Hindu & Christian & \\
\hline \multirow{4}{*}{ Dalit } & \multirow{4}{*}{ Skills of pupils for school gardening: Watering plants } & $\mathrm{n}<5$ & $85.3 \%$ & $13.8 \%$ & $100.0 \%$ \\
\hline & & $\mathrm{n}<5$ & $34.4 \%$ & $50.0 \%$ & $29.9 \%$ \\
\hline & & $\mathrm{n}<5$ & $25.5 \%$ & $4.1 \%$ & $29.9 \%$ \\
\hline & & $63_{\mathrm{a}}$ & $117_{\mathrm{b}}$ & $13_{\mathrm{b}}$ & 193 \\
\hline \multirow{4}{*}{ Janajati } & \multirow{4}{*}{ Skills of pupils for school gardening: Watering plants } & $32.6 \%$ & $60.6 \%$ & $6.7 \%$ & $100.0 \%$ \\
\hline & & $92.6 \%$ & $40.6 \%$ & $40.6 \%$ & $49.7 \%$ \\
\hline & & $16.2 \%$ & $30.2 \%$ & $3.4 \%$ & $49.7 \%$ \\
\hline & & $<5_{\mathrm{a}}$ & $<5$ a & $<5 \mathrm{a}$ & 7 \\
\hline \multirow{4}{*}{ Madhesi } & \multirow{4}{*}{ Skills of pupils for school gardening: Watering plants } & $\mathrm{n}<5$ & $\mathrm{n}<5$ & $\mathrm{n}<5$ & $100.0 \%$ \\
\hline & & $\mathrm{n}<5$ & $\mathrm{n}<5$ & $\mathrm{n}<5$ & $1.8 \%$ \\
\hline & & $\mathrm{n}<5$ & $\mathrm{n}<5$ & $\mathrm{n}<5$ & $1.8 \%$ \\
\hline & & $<5_{\mathrm{a}}$ & $68_{\mathrm{b}}$ & $<5_{\mathrm{a}}$ & 72 \\
\hline \multirow{4}{*}{ Brahmin/Chhetri } & \multirow{4}{*}{ Skills of pupils for school gardening: Watering plants } & $\mathrm{n}<5$ & $94.4 \%$ & $\mathrm{n}<5$ & $100.0 \%$ \\
\hline & & $\mathrm{n}<5$ & $23.6 \%$ & $\mathrm{n}<5$ & $18.6 \%$ \\
\hline & & $\mathrm{n}<5$ & $17.5 \%$ & $\mathrm{n}<5$ & $18.6 \%$ \\
\hline & & 68 & 288 & 32 & 388 \\
\hline Total & & $17.5 \%$ & $74.2 \%$ & $8.2 \%$ & $100.0 \%$ \\
\hline
\end{tabular}

Public school students in Chitwan district of Nepal have different gardening skills in terms of religion and caste. It is found out that Brahmin/Chhetri students who follow Hindus have good knowledge of basic gardening skills comparing with Janajati and Madhesi students with Buddhist and Muslim background. By comparing among the three religion in terms of school gardening skills, students who follow Hinduism have comparatively better gardening skills than that of Buddhist and Christians. Brahmin/Chhetris and Dalit students have skills to ploughing land, sowing seeds, watering plants, taking out weeds and planting crop. Basic gardening skills among the Christian public school students is least on comparison with the rest of two religion. It is found out that Dalit students have comparatively better school gardening skills in comparison with others. It is because their parents work in the field for the livelihood and the knowledge of gardening skills transferred from parents to the children.

The knowledge of school gardening activities help students to understand the science concepts better in the classrooms. It is very interesting fact that school gardening activities help to increase the academic performance of the students.

\section{Conclusion}

The present research aimed to assess the gardening skills by the students at the basic level school students in the public schools at Chitwan and Nawalparasi districts of province no. 3. Findings showed that students who follow Hinduism have relatively good gardening skills such as soil preparation, sowing the seeds in different seasons in the school garden, taking out weeds from the garden, caring and watering plants and using tools in the school garden. These activities help them to understand science concepts which helps for better academic performance. In addition, no significant difference were found among them in accordance with the religion and caste in terms of basic gardening skills. Calculated Phi-value showed a weak relationship and the associations between the variables except the use of tools in the school garden. Furthermore, having the knowledge of basic gardening skills is important for the inquiry based science teaching and learning for the transformation of teacher-centered pedagogy to child-centered approach in teaching and learning science in the public schools in Nepal.

Participatory Action Research (PAR) emphasized both the authentic participation of teachers, students and I as a coresearcher and relevancy of actions in the garden to link it with the school science curriculum. Through cooperative inquiry in the school garden, students work interestingly through the PAR process.

\section{Proposed Research}

The present study believes that conducting these studies will shed more light on the use of school garden for inquirybased science learning to transform the classroom pedagogy in the context of Nepal.

1. Cultivating the enthusiasm among science teachers and students for enquiry-based learning through the provision of school gardening activities outside the structured classrooms in Nepal.

2. Opportunities and challenges to public school science teachers while using garden pedagogy for science teaching and learning in the public schools of Nepal.

3. A proposed professional development training programme for the public school science teachers on garden pedagogy and the design of school science courses. 


\section{Acknowledgements}

This research paper grew out of the insights gained in course of my $\mathrm{PhD}$ pursuit which was:

i registered with the Graduate School of Education, Faculty of Education, Tribhuvan University.

ii inspired by the fellowship for PhD study awarded by NORHED/Rupantaran project.

Therefore, I would like to acknowledge both of the institutions. My special thanks goes to Associate Prof. Kamal Kumar Poudel for his insightful guidance and language edition of the paper.

\section{References}

[1] Capps DK, Crawford BA. Inquiry-based instruction and teaching about nature of science: Are they happening? Journal of Science Teacher Education. 2013 May 15; 24(3): 497-526.

[2] Klemmer CD, Waliczek TM, Zajicek JM. Growing minds: The effect of a school gardening program on the science achievement of elementary students. Hort Technology. 2005 Jul 1; 15(3): 448-52.

[3] Morgan SC, Hamilton SL, Bentley ML, Myrie S. Environmental education in botanic gardens: Exploring brooklyn botanic garden's project green reach. The Journal of Environmental Education. 2009 Jul 1; 40(4): 35-52.

[4] Acharya KP. Science teachers' information processing behaviours in Nepal: A reflective comparative study. Research in Pedagogy. 2007 Aug https://doi.org/10.17810/2015.43

[5] Ozer EJ. The effects of school gardens on students and schools: Conceptualization and considerations for maximizing healthy development. Health Education \& Behavior. 2007 Dec; 34(6): 846-63.

[6] Acharya KP. Fostering critical thinking practices in primary science classrooms in Nepal. Research in Pedagogy. 2006 Oct 6, 2, pp. 1-7. doi: 10.17810/2015.30.

[7] Harlen W. The teaching of science in primary schools. David Fulton Publishers; 2018 Mar 28.
[8] Thorp L, Townsend C. Agricultural education in an elementary school: An ethnographic study of a school garden. In Proceedings of the 28th Annual National Agricultural Education Research Conference in New Orleans, LA 2001 Dec 12 (pp. 347-360).

[9] Krasny ME, Tidball KG. Community gardens as contexts for science, stewardship, and civic action learning. Cities and the Environment (CATE). 2009; 2(1): 8.

[10] Plevyak LH. What do preservice teachers learn in an inquirybased science methods course? Journal of Elementary Science Education. 2007 Mar 1; 19(1): 1.

[11] Rennie LJ. Learning science outside of school. In Handbook of research on science education, Volume II 2014 Jul 11 (pp. 134-158). Routledge.

[12] Herron SS, Magomo D, Gossard PR. The Wheel Garden: Project Based Learning for Cross Curriculum Education. International Journal of Social Sciences. 2008; 3(1): 44.

[13] Hachey AC, Butler DL. Science education through gardening and nature-based play. Young Children. 2009; 64(6): 42-8.

[14] Robinson CW, Zajicek JM. Growing minds: The effects of a one-year school garden program on six constructs of life skills of elementary school children. Hort Technology. 2005 Jul 1; 15(3): 453-7.

[15] Huber RA, Moore CJ. A Model for Extending Hands - On Science to Be Inquiry Based. School Science and Mathematics. 2001 Jan; 101(1): 32-42.

[16] Hirschi JS. Ripe for change: Garden-based learning in schools. Harvard Education Press; 2017 Nov 14.

[17] Skelly SM, Zajicek JM. The effect of an interdisciplinary garden program on the environmental attitudes of elementary school students. Hort Technology. 1998 Oct 1; 8(4): 579-83.

[18] Kelley SS, Williams DR. Teacher professional learning communities for sustainability: Supporting STEM in learning gardens in low-income schools. Journal of Sustainability Education. 2013. 